\title{
THE RESPONSE OF HEART RATE TO HYPOXIA IN MAN AFTER CERVICAL SPINAL CORD TRANSECTION
}

\author{
By Sheila Jennett, M.D. (Liverpool) \\ Institute of Physiology, University of Glasgow
}

Patients with complete spinal transection above the sympathetic outflow lose those reflex responses which depend on efferent pathways from the medullary centres to the spinal cord below the lesion: there is no vasoconstriction in response to a Valsalva manœuvre, no sweating in response to heating the skin, and no increase in heart rate in response to the variety of alarums and excursions which so readily affect it in normal subjects.

Acute hypoxia in normal man and in animals causes tachycardia. The accumulated evidence suggests that this is due to a direct action in the brain, resulting in increased sympathetic activity; this may stimulate the pacemaker both through its sympathetic nerve supply (Downing, 1966) and by means of increased adrenal medullary secretion (Hatcher \& Jennings, I966). There is also increased cardiac output, but not, in man, an increase in arterial blood pressure: vasomotor activity is countered by peripheral vasodilatation particularly in skeletal muscle, as a direct effect of hypoxaemia (Black \& Roddie, I958; Richardson, Kontos, Raper \& Patterson, 1967).

If the tachycardia, increased cardiac output and maintenance of arterial blood pressure associated with hypoxia depend in man on sympathetic pathways from brain to spinal cord, the response could be expected to be abolished following cervical spinal transection. If it persists, alternative mechanisms must be considered.

The present experiments were designed to observe the effect on heart rate and ventilation of brief exposure to Io per cent. oxygen, and of the abrupt reversal of the hypoxia by breathing 100 per cent. oxygen. Similar experiments had been carried out on normal subjects (Jennett, I969), and the extent and repeatability of the expected effects were therefore known. It was of interest to repeat them in spinal subjects because the reported evidence concerning the role of sympathetic activity in hypoxic tachycardia in man is conflicting. Beta-adrenergic blocking agents have been said to diminish the heart-rate response (Richardson et al., 1967), although ganglion-blocking agents have been reported to leave it unaltered (Harris, Bishop \& Segel, I96I).

\section{SUBJECTS AND METHODS}

Eight patients were studied, all of whom were known to have had complete spinal transections at or above $\mathrm{C}_{7}$ (except No. 5, see Table I), for $2 \frac{1}{2}$ months to I6 years. Their age range was 19-60. All were in good general health; the patient most recently injured had been up in a wheelchair for three weeks, and all the others since a short time after injury.

Each subject was studied on two separate occasions within one week: once sitting in a wheelchair, and once lying in bed. The time of day was variable, but no studies were within two hours of a heavy meal. 
TABLE I

Details of spinal patients studied

\begin{tabular}{|c|c|c|c|c|c|}
\hline \multirow[b]{2}{*}{ No. } & \multirow[b]{2}{*}{ Age } & \multirow[b]{2}{*}{$\begin{array}{l}\text { Level of } \\
\text { lesion }\end{array}$} & \multirow[b]{2}{*}{$\begin{array}{l}\text { Time since } \\
\text { injury }\end{array}$} & \multicolumn{2}{|c|}{ Resting heart rate } \\
\hline & & & & Sitting & Lying \\
\hline I & 24 & C7 complete & $8 \mathrm{~m}$. & 60 & 60 \\
\hline 2 & I9 & C6 complete & $9 \mathrm{~m}$. & 80 & $7 \mathrm{I}$ \\
\hline 3 & 36 & C6 complete & I6 yr. & 66 & 75 \\
\hline 4 & 24 & $\mathrm{C}_{7}$ complete & $2 \frac{1}{2} \mathrm{~m}$. & 123 & 78 \\
\hline 5 & 20 & $\begin{array}{c}\text { Complete D2 } \\
\text { incomplete } \\
\text { C4 }\end{array}$ & $4 \mathrm{~m}$ & 75 & $5 \mathrm{I}$ \\
\hline 6 & 46 & C7 complete & $7 \mathrm{~m}$. & 75 & 73 \\
\hline 7 & 40 & C6 complete & I3 yr. & 69 & $8 \mathrm{I}$ \\
\hline 8 & 60 & C7 complete & $8 \mathrm{~m}$. & 97 & 70 \\
\hline
\end{tabular}

Recording Methods. I. Ventilation. Integrated pneumotachography (Mercury Electronics Ltd.) was used to record inspired tidal volume $\left(V_{T}\right)$ for each breath, and 'breath-by-breath-minute-volume' $\left(V_{T} \times f\right.$, where $f$ is respiratory frequency $=\dot{V}_{I}$, for each breath; Greer \& Jennett, I969). These two parameters were recorded on an ultra-violet recorder (S.E.L. Ltd.).

2. Heart Rate. Miniature metal cup electrodes (Grass E-5G) were applied in three chest positions; the ECG was displayed on a cathode-ray oscilloscope (Tektronix 502) which in turn triggered an instantaneous ratemeter (Devices Ltd.) so that beat-by-beat heart rate was recorded on a third channel of the UV recorder.

3. Blood Pressure. This was taken intermittently by automated sphygmomanometry, with a photoelectric pulse monitor on a finger, and stethoscope diaphragm on the contralateral brachial artery.

Inspired Gases. The flow head was placed in the path of inspired gas only, and the subject breathed through a perspex valve box (fig. I). Inspired gas mixtures were delivered from Douglas bags (Plysu Ltd.) through a three-inlet, single-outlet sliding valve; this enabled the inspired concentration of oxygen to be changed between successive breaths, unobtrusively, and with minimal dead space.

The hypoxic mixtures used were $10 \pm 0.5$ per cent. oxygen in nitrogen; the concentration of the contents of each bag was checked immediately before use by the Servomex paramagnetic oxygen analyser.

Experimental Procedure (fig. 2). Ten to fifteen minutes were spent in explanation and in allowing the subject to become accustomed to the apparatus. Continuous recording was started, and ventilation and heart rate allowed to stabilise.

After several minutes breathing air, and at least 2 minutes of reasonably steady recorded levels, Io per cent. oxygen was substituted for 3-4 minutes, then Ioo per cent. oxygen for $\frac{1}{2}$-minute, with uninterrupted recording throughout. This 
PLAN OF AN EXPERIMENT

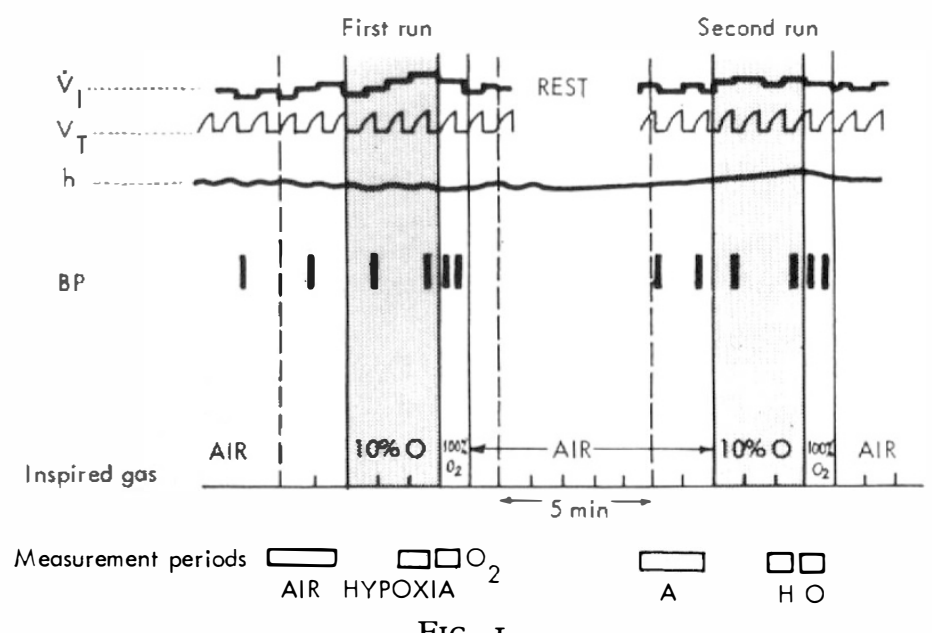

FIG. I

Arrangement of the apparatus for delivering and changing the inspired gases, and for recording ventilation and heart rate. The subject breathes through a mouthpiece, a gauze condenserhumidifier, and perspex valve-box. The flow-head for pneumotachography is placed in the path of inspired gas.

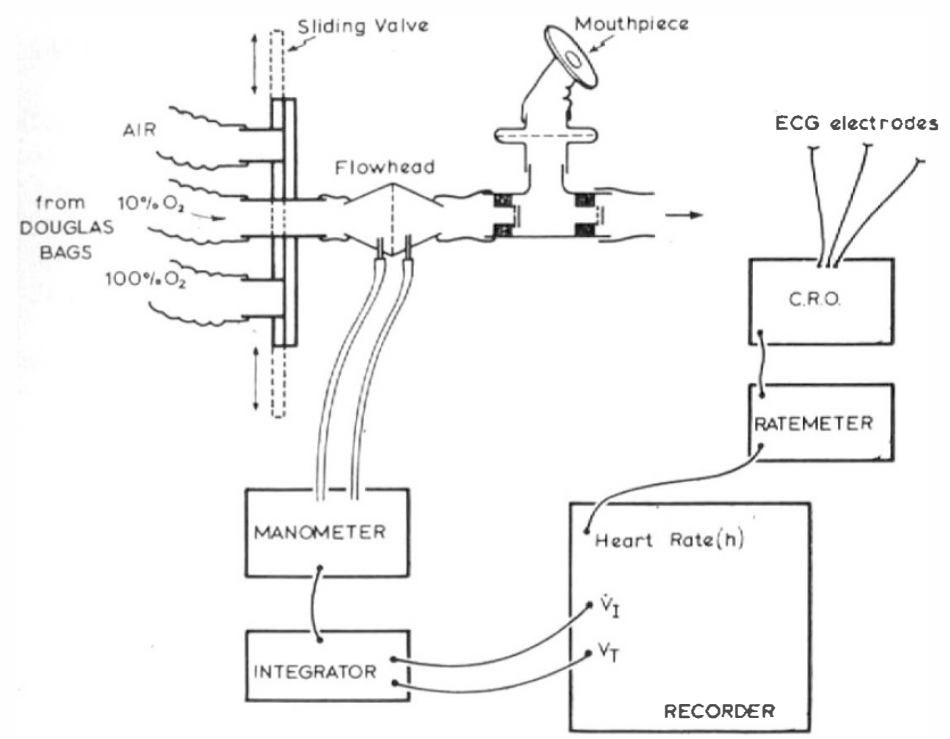

FIG. 2

Diagrammatic representation of experimental procedure. Shaded area: hypoxic period of 3 minutes. $\dot{V}_{I}$ and $V_{T}$ : the two ventilatory parameters, recorded continuously except in the rest period. $h$ : heart rate, recorded throughout. BP: blood pressure, taken at the intervals indicated. Measurement periods: periods for which mean values were found for analysis of changes. 
technique was exactly similar to that previously employed for normal subjects, and the same apparatus was used.

Meanwhile, systolic and diastolic blood pressures were taken at least twice during the air-breathing period, twice during the hypoxic period, and once or twice immediately following re-oxygenation. The time at which B.P. was taken was marked on the UV chart record so that coincident heart rate values could be read. After a short rest, the whole run was repeated once more.

Treatment of Data. I. From the continuous traces, the following values were derived for the periods indicated ('measurement periods', fig. 2).

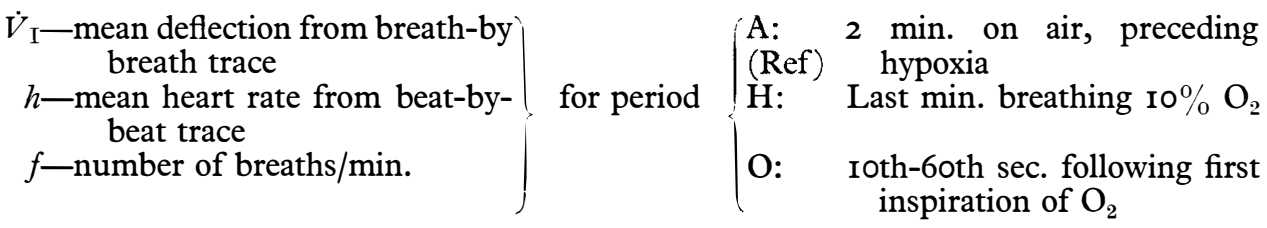

2. Heart rates corresponding to each blood pressure reading were found.

3. The re-oxygenation period was examined for the clear decrease in heart rate and/ or in ventilation, which is almost invariably found in normal subjects (fig. 4). If such changes were identifiable, the elapsed time from the beginning of the first breath of oxygen was measured.

In this way eight sets of data were assembled. For various technical reasons not all patients had all measurements successfully recorded.

Heart Rate. Six complete sets of results were available, with two values for each subject in each posture, and for each inspired oxygen concentration (' $\mathrm{O}_{2}$-level'). A 3 -factor analysis of variance was carried out to assess the variation in heart rate between subjects, between postures, and due to altered $\mathrm{O}_{2}$-level. 2-factor analysis was carried out for each posture separately.

Since changes in heart rate were more consistent and of greater extent when the subjects were lying than when they were sitting, and since the normal subjects had been studied semi-recumbent, most further analyses were carried out on the 'lying' results only.

Ventilation. Five complete sets of results were analysed by 2-factor analysis of variance, to discover the significance of the effect of $\mathrm{O}_{2}$-level on ventilation.

Blood Pressure. Six sets of results were analysed in terms of mean B.P. and systolic B.P. to assess the effect of $\mathrm{O}_{2}$-level on B.P.

The mean values (with standard deviations and errors) for each variable for all runs on all subjects were also found, and appropriate comparisons made between the different conditions by Student's $t$-test; such comparisons were also applied to the changes in ventilation and in heart rate expressed as a percentage of the reference air-breathing values, so that all results for all subjects were made comparable and pooled.

\section{RESULTS}

Figure 3 shows a typical record of the last part of the hypoxic period and the switch to IOO per cent. oxygen Figure 4 shows a comparable one from a normal subject. In both, the heart rate had increased by IO-I 5 beats, and decreased back to the normal level within 20 seconds of the first breath of oxygen. The normal subject also showed a depression of ventilation on re-oxygenation.

An increase in heart rate above reference level during hypoxia, and an abrupt decrease shortly following re-oxygenation, occurred in spinal as in normal subjects; neither the extent nor the timing of the changes was notably different from normal. 


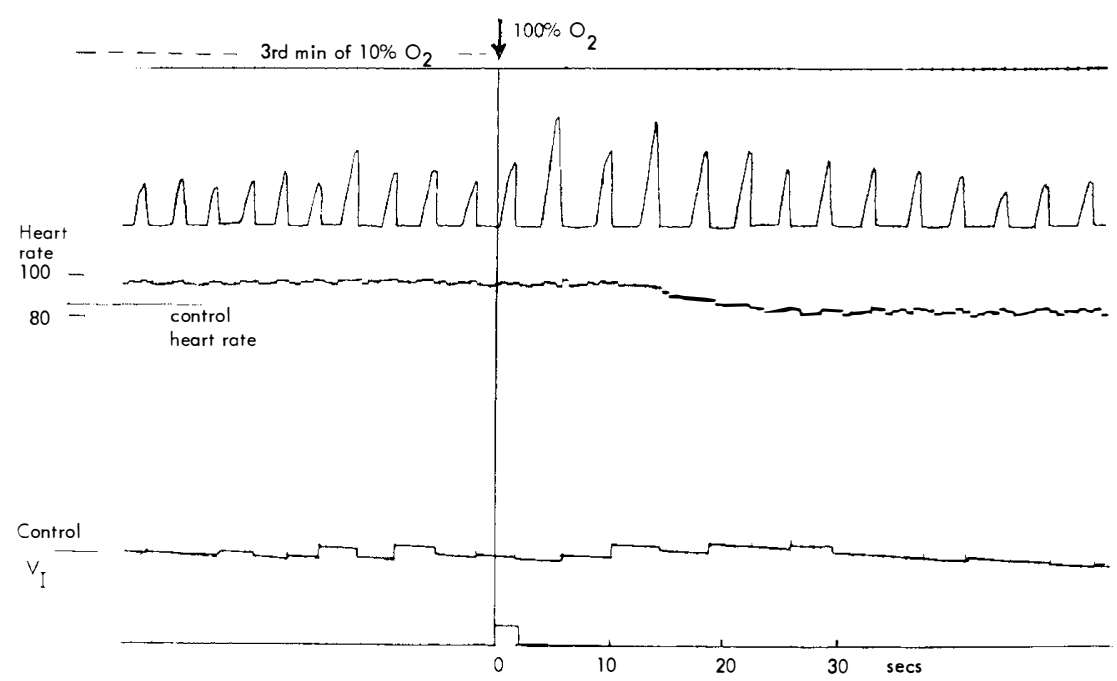

FIG. 3

Subject with cervical spinal cord transection: record of the final half-minute breathing Io per cent. oxygen, and of the relief of the hypoxia by abrupt change to IOo per cent. oxygen.

Upper trace: tidal volume

Lower trace: breath-by-breath minute volume

$\nmid$ no marked changes.

Middle trace: the heart rate has risen during hypoxia by I I-I 2 beats per minute. It decreases to control level abruptly after a short delay from the first breath of oxygen.

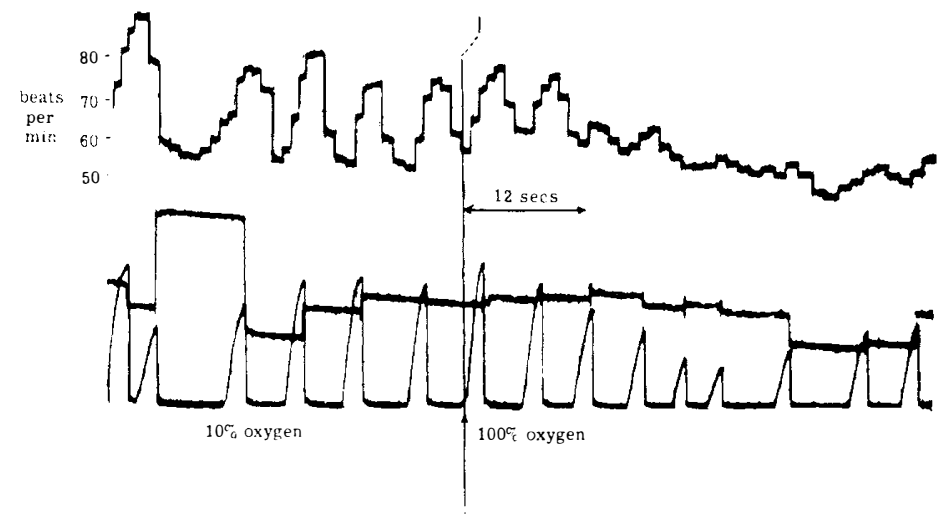

Normal subject - decrease in ventilation and in heart rate on reoxygenation after $3 \mathrm{~min}$ hypoxia

FIG. 4

Normal subject: record of comparable part of a similar experiment to that represented in Figure 3. Upper trace: heart rate: (Scale is twice that in Figure 3, so that changes appear larger) sinus arrhythmia very marked; heart rate was 15 beats per minute above control in last minute of hypoxia. There is an abrupt decrease shortly after the switch to oxygen. Lower traces: the two ventilatory parameters, there is a depression of ventilation after the first few breaths of oxygen. 
Ventilation usually increased measurably during hypoxia, but the characteristic normal decrease on re-oxygenation was not demonstrable in most runs on spinal subjects.

The mean values for all subjects as percentage changes from air-breathing values, are shown in Figure 5 and compared with previous results for normal subjects.

Because the changes under discussion are small it was necessary to carry out appropriate analysis to demonstrate their significance.

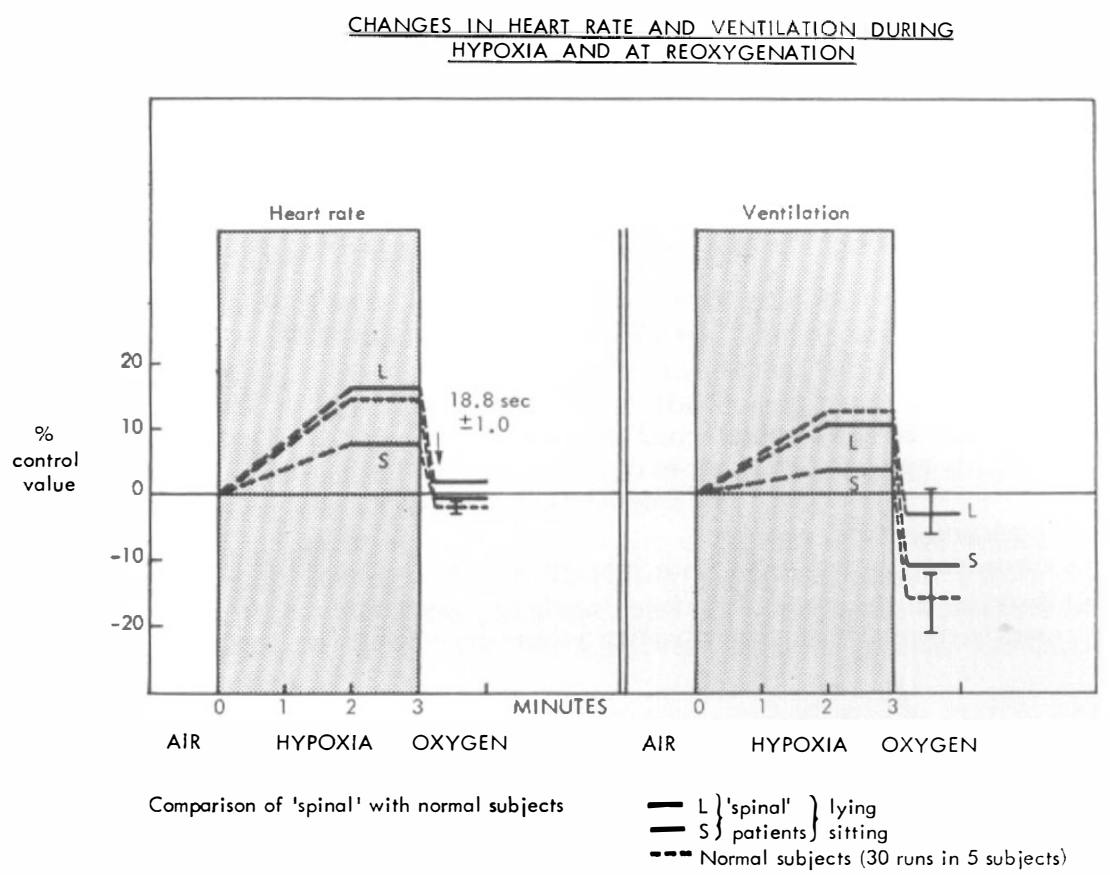

FIG. 5

Mean changes in heart rate and in ventilation during hypoxia and re-oxygenation, expressed as percentage of air-breathing values. The increases in both heart rate and ventilation are shown to be similar in normal and in spinal subjects when they were recumbent. Error bars show standard errors of the mean changes on re-oxygenation. Arrow indicates delay time for heart rate decrease in spinal subjects.

Cardiovascular Changes. Heart Rate. The mean results, together with their statistical significance, are shown in Table II and Figure. 6. Changes are also shown in Figure 5.

The mean increase in heart rate was by about 16 per cent., or Io beats per minute when the subjects were lying, and both this and the decrease on reoxygenation were significant. (In the sitting posture, the average increase was 8 per cent., about 5 beats per minute, and was not significant by comparison of means.) Analysis of variance showed, however, that the effect of $\mathrm{O}_{2}$-level on heart rate was highly significant in either posture (lying, $\mathrm{P}<0.001$; sitting $\mathrm{P}<0.01$ ).

Comparison with Normal Subjects (Table III). Seven normal and seven spinal 


\section{TABLE II}

Mean results for six subjects from analysis of variance

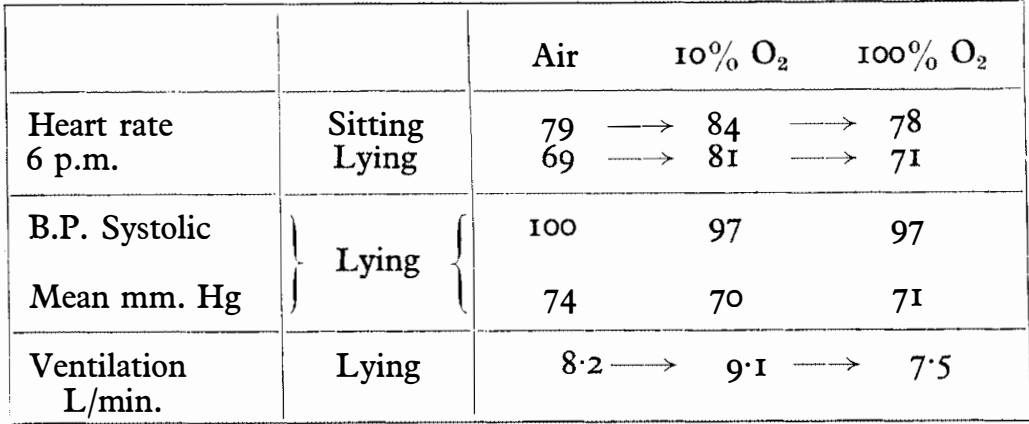

Significant difference)

BLOOD PRESSURE AND HEART RATE BREATHING AIR (A), IN 3rd MIN OF $10 \% \mathrm{O}_{2}$ (H) AND ist MIN OF OXYGEN (Q)

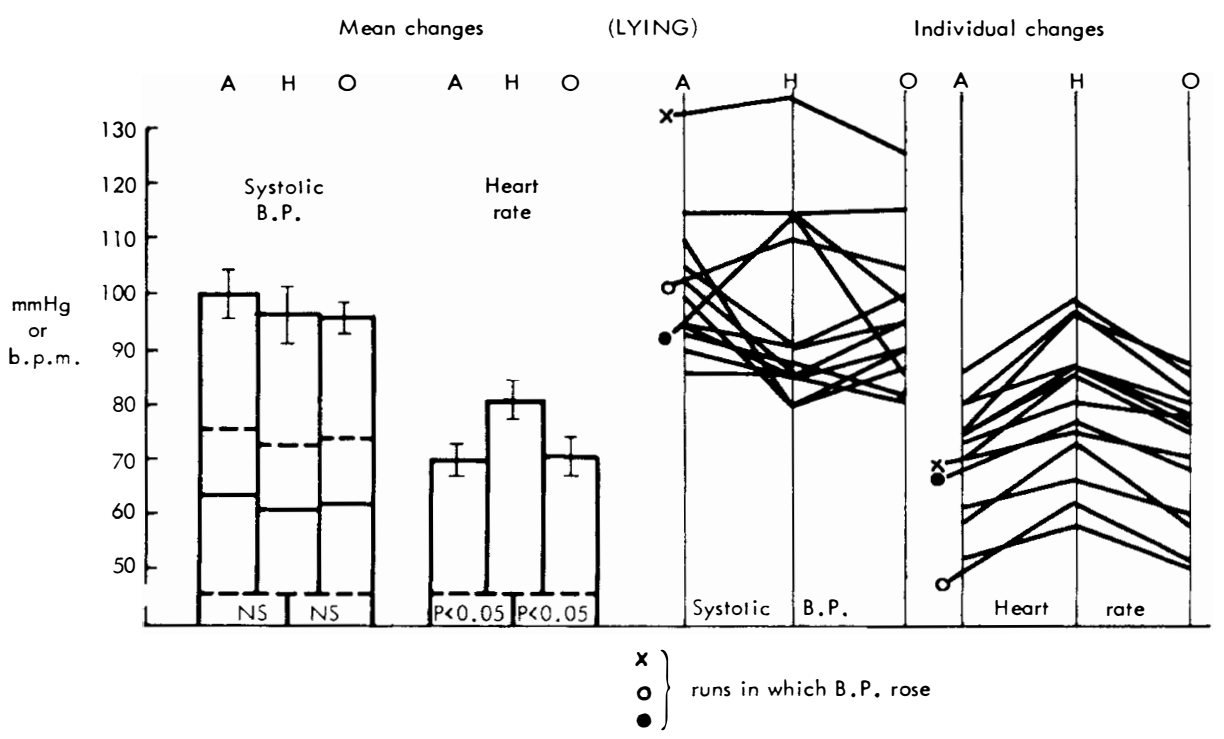

Fig. 6

Spinal subjects: Mean changes, (left) and individual changes (right) in systolic blood pressure and in heart rate, during hypoxia and re-oxygenation. (The runs in which B.P. rose are marked, in order to indicate that heart rate increased in these runs also.) 
TABLE III

Changes in heart rate. Mean results and comparisons between spinal and normal subjects by analysis of variance

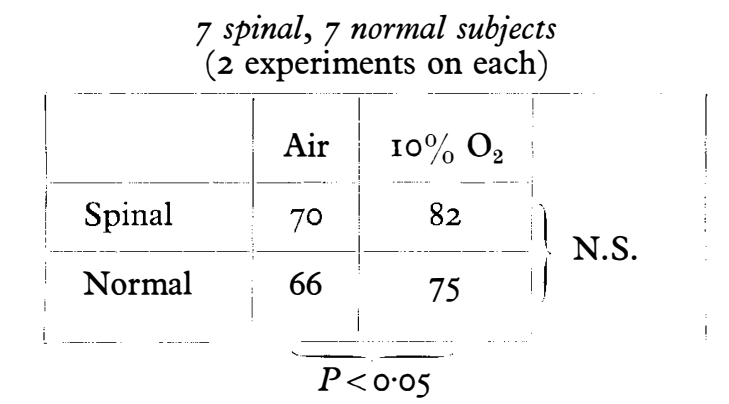

\begin{tabular}{|c|c|c|c|c|}
\hline & $\begin{array}{l}4 s p i \\
(2 \mathrm{e}\end{array}$ & $\begin{array}{l}l, 4 \text { norm } \\
\text { eriments }\end{array}$ & $\begin{array}{l}\text { ubjects } \\
\text { each) }\end{array}$ & \\
\hline & Air & $10 \% \mathrm{O}_{2}$ & $100 \% \mathrm{O}_{2}$ & \multirow{3}{*}{ N.S. } \\
\hline Spinal & $7 \mathrm{I}$ & 83 & 74 & \\
\hline Normal & 69 & 80 & 68 & \\
\hline
\end{tabular}

subjects were compared by analysis of variance for the effect of hypoxia on heart rate. This effect was again shown to be significant, and there was no difference in the effect attributable to spinal transection.

Four complete replicated experiments for both the change to hypoxia and the re-oxygenation, for spinal and normal subjects respectively were similarly analysed. Again there was no difference in the effect of $\mathrm{O}_{2}$-level, attributable to spinal transection.

Timing of Decrease in Heart Rate on Re-oxygenation. The first clear decrease in heart rate occurred after an average delay of 18.8 seconds from the beginning of the first breath of oxygen. Although this is suggestive of a longer delay than in 30 runs on normal subjects (mean I 5.9 seconds) comparison by $t$-test showed that the difference fell short of significant.

Blood Pressure. In most runs in the lying posture, and a majority in the sitting posture, the systolic blood pressure decreased during hypoxia (fig. 6). There was an average decrease, but the three exceptions made this non-significant.

Analysis of variance for six subjects lying, led to the conclusion that there was no significant effect of $\mathrm{O}_{2}$-level on blood pressure, whether pulse pressure, mean B.P. or systolic B.P. were considered. The blood pressure was very variable between subjects. The mean values are shown in Table II.

Relationship between Changes in Blood Pressure and Changes in Heart Rate. It appeared possible that if abrupt fortuitous increases in B.P. were excluded, there might be a fall in B.P. during hypoxia in these subjects which could account for the rise in heart rate; all measurements were expressed as a deviation from the subject's air-breathing mean value, and change in heart rate plotted against change in ventilation using all available pairs of data. There was a large scatter, but the points representing the measurements made during hypoxia showed a correlation $(r=-0.66)$ which was highly significant. 
Ventilation. When subjects were lying, ventilation increased in almost all instances during hypoxia, by an average of II 5 per cent. This was similar to the findings for normal subjects. Variation between the spinal subjects was, however, such that there could not be shown to be a significant increase by comparison of mean values for the reference period with those for the last minute of hypoxia.

Reduction of ventilation at re-oxygenation was less often seen than in normal subjects, so that the mean decrease for all runs was much smaller: this difference from the normal did not reach significance (note large standard errors for the values after re-oxygenation, fig. 6). It was virtually never possible to define an abrupt decrease in ventilation during the first half-minute of breathing oxygen.

Analysis of Variance for five subjects with complete data in the lying position showed that the effect of the oxygen level on ventilation was highly significant $(\mathbf{P}<0.001)$.

The mean values for these five subjects are shown in Table II.

\section{DISCUSSION}

Methods, and Validity of Findings. The recording of heart rate presented no difficulties; there is no uncertainty about the values obtained. In these subjects, on account of the absence of the influence of higher centres, the heart rate was much steadier than in normal subjects, and a prolonged settling down period was not necessary.

Somewhat less confidence can be placed in the measurements of blood pressure since artefacts were possible in the automatic device, and the measurements occasionally failed unexpectedly, or were made difficult by the flexion of the elbow.

The recording of ventilation was usually straightforward. In one subject who breathed with a very small tidal volume in the sitting position, the pneumotachograph output may not have been accurately related to inspired volume. The mean absolute values for ventilation show a resting level rather on the high side of normal, but not such as to suspect that hyperventilation occurred to any important extent. It was unfortunate that circumstances did not allow of the measurement of endtidal $\mathrm{CO}_{2}$ concentration to check this point. However, the average increases in ventilation during hypoxia were similar in this group to those in normal subjects, known to have a normal $\mathrm{CO}_{2}$, so that they are almost certainly comparable.

Interpretation and Significance of Results. When these subjects were made mildly hypoxic, their heart rate increased in a similar pattern to normal subjects. This can be taken to imply either that the pathways normally employed are those still intact in the quadriplegic subjects, or that different ones are used which lead to similar changes. Also the decrease following re-oxygenation was similarly abrupt and occurred after a similar delay though with a slight tendency to a longer time-lag. This delay includes the time required for filling apparatus dead space and for alveolar mixing, as well as circulation time from the lungs to the site of action.

A mechanism, or mechanisms, leading to the tachycardia during hypoxia, which could operate equally and similarly in normal and spinal subjects, would have to be compatible with the following

I. The site of action of hypoxaemia in initiating the response must be in connection with the effector (the SA node) in both groups. 
2. This site of action must be where the effect of hypoxaemia upon it could be reversed within about 8-Io seconds of fully oxygenated arterial blood leaving the pulmonary capillary bed.

Possible Sites of Action. Arterial Chemoreceptors. Pathways from these receptors to the medulla, and the effector route for an increase in ventilation, are intact in the spinal subjects: the ventilatory increase during hypoxia was normal in these subjects. In dogs, the tachycardia of hypoxia is partly secondary to the increased ventilation, by means of vagally mediated reflexes, and stimulation of the carotid bodies primarily leads to bradycardia (Daly \& Scott, I962). In man, changes in heart rate cannot, however, be attributed to a secondary effect of ventilatory stimulation, since the two responses were not linked in either extent or timing, either in these spinal subjects or the normal series (Jennett, I969).

The absence of the usual ventilatory depression during the first few breaths of oxygen was striking, though no clear significance can be placed upon it without further study. If there are real differences, they could be attributed to the absence of an intact sympathetic efferent pathway from the medulla; the autonomic control of carotid body blood flow and oxygen consumption has been demonstrated to be of importance in determining the sensitivity to hypoxaemia (Purves, I969).

The aortic chemoreceptors are not excluded, since it is possible that the stimulation may lead directly to tachycardia (Comroe \& Mortimer, 1963); the efferent pathway would require to be vagal inhibition only, in order to account for the normality of response in the spinal subjects.

The medullary cardiovascular centres are commonly held to respond to the direct effect of hypoxia; theoretically, such an effect could result in tachycardia either by sympathetic stimulation or vagal inhibition. In experimental animals, increased activity has been demonstrated in the cardiac sympathetic nerves in response to hypoxia of the brain when the rest of the body is normoxic (Downing, Mitchell \& Wallace, I963). There appears to be no good evidence of vagal inhibition by hypoxia of the C.N.S.

In normal subjects, the present type of study has shown that the tachycardia of mild hypoxia disappears on re-oxygenation at least as rapidly as the increased ventilation; this makes a medullary site of action doubtful, as there is evidence that in man as well as in dogs, step changes in inspired gas concentrations act more rapidly via the arterial chemoreceptors than via the medulla (Gelfand, Lamberthen \& Downes, 1964).

Adrenal Medulla. Direct central action of severe hypoxia is known to increase sympathetic outflow and the effects include increase in adrenal medullary secretion. There is no evidence of a measurable increase in circulating catecholamines in man at the moderate level of hypoxia induced by breathing 8-10 per cent. oxygen (Richardson et al., 1967). This negative finding does not, however, necessarily exclude adrenal medullary action in man: very small amounts of catecholamines and perhaps an unrecognised cardiotonic agent may be responsible; there is evidence for this in dogs (Hatcher \& Jennings, I966). The normal response in spinal subjects is against this mechanism, unless the adrenals could be affected directly, or their sympathetic supply influenced in the spinal cord itself. Also the abruptness of the return to normal heart rate on re-oxygenation is more compatible with a neural reflex than with destruction of a circulating chemical factor.

Spinal Cardiovascular Centres. There is some evidence that hypoxia can 
stimulate spinal sympathetic neurones (Alexander, I945). This explanation could account for both the spinal and normal results, provided that re-oxygenation could occur at this site sufficiently rapidly, to be compatible with the short delay time.

The Heart Itself. There appears to be no unequivocal evidence in the literature to rule out the attractive hypothesis of direct hypoxic stimulation of the pacemaker (Heymans \& Neil, I958), however, the effect of acidity is bradycardia, and cellular hypoxia increases acidity.

The Pulmonary Circulation. The degree of hypoxia induced in these experiments can be assumed to cause increased pulmonary vascular resistance, according to reported findings in animals and man. In the only published record so far found, it appears that the change is reversed within 20-30 seconds of switching off the hypoxic mixture (Doyle, Wilson \& Warren, 1952). Increased PAP could possibly be linked with increase in heart rate, if it leads to increase in left atrial pressure (Ledsome \& Linden, 1967); the pathway for this reflex, however, is vagal afferent, sympathetic efferent, so it would not be expected to operate normally in spinal subjects.

The Peripheral Circulation. Hypoxaemia has a local direct vasodilatory effect; in normal subjects this is ordinarily balanced by reflexly stimulated vasoconstriction, so that there is no consistent change in arterial blood pressure. There was a greater tendency for B.P. to decrease during hypoxia in most runs on spinal subjects; this difference is consistent with the absence in spinal subjects of a normal vasoconstrictor response to hypoxia: also it is evidence against there being any direct or reflex stimulation of sympathetic activity in the isolated spinal cord, and therefore against such stimulation as an explanation of the tachycardia. The significant correlation between deviations from reference value of B.P. and of heart rate during hypoxia in spinal subjects tends to support the contribution of peripheral vascular effects: it suggests a decrease in blood pressure leading to an increase in heart rate via the baroreceptors and vagal inhibition. There are, however, objections to this explanation

I. In normal subjects the B.P. does not consistently change: this is clearly not the explanation for them, and it would seem unlikely that changes so similar in extent and in timing should be produced in the two sets of subjects by two completely different mechanisms.

2. Reversal would be longer delayed if it depended on peripheral re-oxygenation.

3. In the instances when blood pressure became for some reason higher during hypoxia in the spinal subjects, there was nevertheless an increase in heart rate (fig. 6).

\section{CONCLUSIONS}

The observation that the behaviour of heart rate during hypoxia and reoxygenation is similar in normal and spinal subjects, is difficult to reconcile with any of the proposed mechanisms. It can be concluded that direct or reflex medullary stimulation, taking effect by means of the sympathetic pathway to the sinoauricular node is not the mechanism, or not the only mechanism whereby hypoxia causes tachycardia in man.

Dr. J. J. Walsh kindly gave permission for this study to be carried out, and made the facilities available, at the National Spinal Injuries Centre, Stoke Mandeville. Dr. H. L. H. Frankel gave invaluable help in selection of subjects and organisation. 


\section{SUMMARY}

The tachycardia which accompanies hypoxia is usually thought to be due to medullary stimulation and increased sympathetic activity. The present results indicate that an intact sympathetic pathway from medulla to spinal cord is not essential to the normal pattern of heart rate changes during hypoxia and reoxygenation.

Eight subjects with complete cervical spinal cord transection were studied. They were given Io per cent. oxygen to breathe for 3 minutes, and the hypoxia was then abruptly relieved by switching to Ioo per cent. oxygen. Heart rate and ventilation were recorded throughout, and blood pressure was measured intermittently. The heart rate increased by an average of about ro beats per minute, and decreased rapidly to normal after an average delay of 18.8 seconds from the first breath of oxygen. Neither the extent nor the timing of these changes was significantly different from those found previously by a similar technique in normal subjects. The changes in heart rate were not consistently linked to changes in ventilation or in blood pressure.

Possible mechanisms for the heart-rate changes have been considered in the light of these results and those in normal subjects. If the site of action is medullary, the efferent pathway must be vagal; alternatively the action must be on the sympathetic system below the lesion, or a direct effect on the cardiovascular system.

\section{RÉSUMÉ}

On pense que la tachycardie accompagnant l'hypoxémie est habituellement due à une stimulation bulbaire et une augmentation de l'activité du système sympathique. Les résultats publiés dans cet article indiquent qu'un système sympathique intact entre le bulbe et la moëlle épinière n'est pas essentiel dans la régulation du rythme cardiaque pendant l'hypoxémie et la réoxigénation.

Huit sujets, avec des transections complètes de la moëlle épinière, ont été étudiés. On leur a donné 10\% d'oxygène à respirer pendant trois minutes et l'hypoxie a été brutalement enrayée en passant à 100\% d'oxygène. Le rythme cardiaque et respiratoire a été enregistré d'une façon permanente, et les changements de pression artérielle mesurés d'une façon intermitente. Le rythme cardiaque a augmenté d'environ Io battements par minute, et rapidement ramené à la normale après un délai moyen de 18,8 secondes à partir de la première prise d'oxygène. Il n'a pas été noté de différence sensible avec une technique similaire appliquée sur des sujets normaux. Les changements du rythme cardiaque n'ont pas été correlés d'une façon consistante aux changements de ventilation ou de tension artérielle.

Des mécanismes possibles, portant sur des modifications du rythme cardiaque ont été considérés à la lumière de ces résultats et de ceux des sujets normaux. Si le Centre de régulation est médullaire, le système vagal doit être la partie éfférente; ou, alternativement, le mécanisme concernerait le système sympathique au-dessous de la lésion, ou aurait un effet direct sur le système cardio-vasculaire lui-même.

\section{ZUSAMMENFASSUNG}

Die Tachykardie, welche die Hypoxia begleitet, wird gewöhnlich als Folge medullärer Reizung und vermehrter sympathischer Aktivität angesehen. Die augenblicklichen Resultate zeigen, dass eine intakte sympathische Nervenleitung von der Oblongata zum Rückenmark für das normale Bild der Veränderungen des Herzschlags während der Hypoxia und Reoxigenation nicht wichtig ist.

Acht Tetraplegiker mit kompletter Querschnittslähmung wurden untersucht. Ihnen wurde $10 \%$ Sauerstoff für 2 Minuten zum Atmen gegeben und dann wurde die Hypoxia 
plötzlich durch Zufuhr von $100 \%$ Sauerstoff unterbrochen. Herzrate und Ventilation wurden dauernd bestimmt und Blutdruck wurde intermittierend gemessen. Der Herzschlag nahm im Durchschnitt um Io Schläge pro Minute zu und kehrte schnell zur Norm zurück, im allgemeinen nach I 8.8 Sekunden seit dem ersten Einatmen von Sauerstoff. Weder die Intensität noch die Dauer dieser Veränderungen unterschieden sich von denen, welche früher mit der gleichen Technik bei Normalen gefunden wurden. Die Änderungen des Herschlages stimmten nicht absolut mit den Änderungen der Ventilation und des Blutdrucks überein.

Die möglichen Mechanismen für die Herzveränderungen werden im Lichte dieser Resultata und denen der Normalen diskutiert. Wenn man die Lokalization der Aktion in der Oblongata annimmt, dann ist der Vagus die efferente Leitungsbahn. Als alternative Aktion muss das sympathische System unterhalb der Läsion angenommen werden oder sie ist ein direkter Effekt des kardiovaskulären Systems.

AleXANDer (I945).

\section{REFERENCES}

Black, J. E. \& RodDie, I. C. (1958). The mechanism of the changes in forearm vascular resistance during hypoxia. Fournal of Physiology, 143, 226-235.

Comroe, J. H. JNR, \& MORTimer, L. (1963). Cardiovascular and respiratory effects of sodium cyanide, nicotine, phenyldiguanide and serotomin on the aortic chemoreceptors, separated temporally from the carotid bodies. Pharmacologist, 5, 259.

DALY, M. DE B. \& SCOTT, MARY T. (I962). An analysis on the primary cardiovascular reflex effects of stimulation of the carotid body chemoreceptors. Fournal of Physiology, I62, 555-573.

DownING, S. E. (1966). Autonomic influences on cardiac function in systemic hypoxia. In Proceedings International Symposium on the Cardiovascular and Respiratory Effects of Hypoxia, Kingston, Ont., I965. Ed. Hatcher, J. D. \& Jennings, D. B., pp. 208-23I. Basel/New York: Karger.

Downing, S. E., Mitchell, J. H. \& Wallace, A. G. (1963). Cardiovascular responses to ischaemia, hypoxia and hypercapnia of the central nervous system. American fournal of Physiology, 204, 88I-887.

Doyle, J. T., Wilson, J. S. \& WARREN, J. V. (I952). Pulmonary vascular responses to short term hypoxia in human subjects. Circulation, 5, 263-270.

Gelfand, R., Lamberthen, C. J. \& Davies, J. (1964). Use of $\mathrm{CO}_{2}$-induced respiratory transients in analysis of respiratory control mechanisms. The Physiologist, 7, I4I.

GreER, J. R. \& JENNETT, SHEILA (I969). An integrated pneumotachopaph system including breath-by-breath measurement of ventilation rate (minute volume). Fournal of Physiology, 200, 92-94.

Harris, P., Bishop, J. M. \& Segel, N. (I96I). The influence of guanethidine or hypoxic pulmonary hypertension in normal man. Clinical Science, 21, 295-300.

Hatcher, J. D. \& Jennings, D. B. (I966). Evidence for the role of humoral mechanisms in the cardiovascular responses to hypoxia and anaemia. In Proceedings International Symposium on the Cardiovascular and Respiratory Effects of Hypoxia, Kingston, Ont. I965, pp. I74-I 88. Basel/New York: Karger.

Heymans, C. \& Neil, E. (1958). Reflexogenic Areas of the Cardiovascular System. London: Churchill.

JenNETT, SHEIla (1969). Changes in ventilation and heart rate during and after brief moderate hypoxia in resting man. Fournal of Physiology, 200, 106-107.

Ledsome, J. R. \& Linden, R. J. (I967). The effect of distending a patch of the left atrium on the heart rate. Fournal of Physiology, 193, I2 I-I29.

Purves (I969).

Richardson, D. W., Kontos, H. A., Raper, A. J. \& Patterson, J. L. (I967). Modification by Beta-adrenergic blockade of the circulatory responses to acute hypoxia in man. fournal of Clinical Investigation, 46, 77-85. 